Wojciech Kucharski ${ }^{1}$

[Wrocław ]

\title{
Autorstwo i prawa autorskie do relacji oral history wolsce
}

Wrocławski Rocznik

Historii Mówionej

Rocznik VIII, 2018

ISSN 2084-0578

DOI: $10.26774 /$ wrhm.205

\section{Wprowadzenie}

Środowiska, instytucje i badacze zajmujący się od wielu lat nagrywaniem, zbieraniem i analizowaniem relacji historii mówionej w Polsce nie dysponują jasnym i dla ich pracy fundamentalnym orzeczeniem dotyczącym autorskoprawnej kwalifikacji relacji oral history. Prezentowany tekst nie rości sobie pretensji do ostatecznego rozstrzygnięcia tej kwestii i wyczerpania tematu. Jest raczej głosem zachęcającym do dyskusji środowisko prawnicze, tym bardziej że zabiera go historyk, a nie prawnik.

Problematyka praw autorskich do relacji oral history nie została dotąd w Polsce szczegółowo opracowana, zaś badacze podzieleni są nawet w tak istotnej sprawie, jak przynależność autorskich praw osobistych i majątkowych do relacji. Istotną w tym rolę odgrywa podstawowa kwestia definicji pojęcia relacji². Według Oral History Association - i chyba także Polskiego Towarzystwa Historii Mówionej - oral history to rejestrowany wywiad narracyjny skupiony na indywidualnym doświadczeniu przeszłości, dający opowia-

1 https://orcid.org/oooo-ooo2-1599-5659.

2 M. Kierzkowski, Historia mówiona - próba definicji pojęcia, „Wrocławski Rocznik Historii Mówionej", R. 4 (2014), s. 5-20. 
dającemu możliwość jak najpełniejszego przekazania swego doświadczenia i podzielenia się refleksją nad nim, nieograniczony czasowo, do którego to wywiadu mówca posiada pełnię praw autorskich ${ }^{3}$.

Izabela Lewandowska, analizując miejsce przekazów ustnych w źródłoznawstwie historycznym, wskazała, że wywiad narracyjny to najwęższe rozumienie źródła oralnego, zastanawiała się także, czy w szerszym rozumieniu za źródła tego typu - choć nasuwa to pewne wątpliwości - można uznać: wywiad prasowy, stenogram dyskusji, przemówienia sejmowe, wykłady profesorów, reportaże radiowe i telewizyjne, wywiady rzeki itp. ${ }^{4}$ Idąc tym tropem, Anna Żeglińska wprost stwierdziła, że

relacje oral history mogą być przekazywane w formie wywiadu, wypowiedzi, opinii, oceny, komentarza, przemówienia, wykładu, reportażu, transmisji, wspomnienia - uczestników wydarzeń, o znaczeniu dla historii, polityki, gospodarki, kultury itd., jak również w postaci folkloru (piosenki, przyśpiewki, anegdoty, przypowieści), świadomie zorganizowanej przez badacza (historyka, archiwistę) ${ }^{5}$.

Gdyby uznać, że oral history to także autobiograficzna refleksja, która powstaje w wyniku działania samego narratora, i przyjąć, że jest ona utworem w rozumieniu Ustawy o prawie autorskim i prawach pokrewnych (o czym niżej), to narratora należy uznać za twórcę utworu, którym jest relacja. Zatem zgodnie z ustanowioną w art. 8 ustawy zasadą twórcy, to jemu przysługuje pełnia praw autorskich ${ }^{6}$. W tym miejscu sygnalizuję tylko problem braku spójnej i akceptowalnej definicji oral history i wynikających z tego konsekwencji dotyczących autorstwa. Jednocześnie zastrzegam,

3 Cyt. za: M. Kurkowska-Budzan, Informator, świadek historii, narrator - kilka wątków epistemologicznych $i$ etycznych oral history, „Wrocławski Rocznik Historii Mówionej", R. 1 (2011), s. 11.

$4 \quad$ I. Lewandowska, Źródła oralne w warsztacie badawczym historyka dziejów najnowszych $i$ w edukacji historycznej, [w:] Źródła w edukacji historycznej. III Toruńskie Spotkania Dydaktyczne, red. S. Roszak, M. Strzelecka, A. Wieczorek, Toruń 20o6, S. 157 .

5 A. Żeglińska, Relacje oral history jako obiekty archiwalne, „Archiwa-Kancelarie -Zbiory", nr 2(4) (2011), s. 146.

6 Ustawa z dnia 4 lutego 1994 r. o prawie autorskim i prawach pokrewnych (tekst jedn.: Dz.U. z 2018 r., poz. 1191). W dalszej części artykułu przywołuję zapisy Prawa autorskiego za niniejszą podstawą. 
że wielość definicji ma także swoje zalety, choć trudno przyjąć, że każdą rozmowę lub narrację autobiograficzną można uznać za historię mówioną ${ }^{7}$

Na potrzeby dalszej części wywodu przyjmuję, że relacja oral history to nagrany w postaci audio lub audio-wideo wywiad narracyjny dotyczący życia narratora/świadka historii, nieograniczony w czasie ${ }^{8}$. W powstaniu relacji oral history muszą uczestniczyć co najmniej dwie osoby: informator/ narrator/świadek historii ${ }^{9}$ prezentujący retrospektywną opowieść o swoim życiu i badacz, który moderuje rozmowę i wywołuje wspomnienia ${ }^{10}$. W dalszej części wywodu pominę kwestie związane z transkrypcją, opracowaniem i opublikowaniem relacji, gdyż wymagałyby to osobnej analizy, choć w tej materii można pójść przetartymi szlakami, stosując analogie np. do wydań i opracowań biograficznych źródeł historycznych. W kontekście analiz autorskoprawnych należałoby natomiast rozważyć kwalifikowanie opracowania (krytycznej edycji źródłowej relacji) jako utworu zależnego. Pozostawiam jednak tutaj i tę kwestię bez rozwiązania ${ }^{11}$.

Przyjmując wskazane założenia, będę chciał przedstawić następujące kwestie: relacja oral history jako utwór; kim jest autor relacji oraz jakie przesłanki należy spełnić, aby stać się autorem relacji w rozumieniu prawa autorskiego; z jakimi autorskimi prawami mamy do czynienia w przypadku relacji; kto dysponuje prawami autorskimi do relacji i w jakim zakresie; w jaki sposób kwestia praw autorskich funkcjonuje w praktyce działań instytucji zajmujących się zbieraniem i archiwizowaniem relacji oral history.

Moje rozważania będą dotyczyć przede wszystkim polskiej rzeczywistości kulturowej i prawnej z pewnymi odniesieniami do analogii w innych krajach.

$7 \quad$ L. Ratkowska-Widlarz, [rec.] Eksperyment(y) na oral history (J.P. Fereński, Kierunek eksperymentalny. Początki pierwszych w Polsce studiów kulturoznawczych, Wrocław 2012, ss. 191), „Wrocławski Rocznik Historii Mówionej”, R. 4 (2014), s. 276-282.

8 Nie rozstrzygam w tym miejscu, czy relacja oral history jest ze swej definicji utworem audiowizualnym. Warto jednak już teraz zwrócić uwagę na dyskusję wokół pojęcia utwór audiowizualny, zob.: J. Barta, R. Markiewicz, Prawo autorskie, Warszawa 2016, s. 309-311.

9 Badacze posługują się różnymi terminami na określenie osoby, której relacja jest nagrywana. Najczęściej używane są pojęcia: „informator”, „świadek historii”, „narrator”. W dalszej części pracy będę posługiwał się tymi pojęciami zamiennie.

10 M. Kierzkowski, op. cit., s. 7.

11 J. Barta, R. Markiewicz, op. cit., s. 83-84. 
Kluczową kwestią dla niniejszych rozważań jest ustalenie, czy relacja oral history mieści się w pojęciu utworu (dzieła). Kwestia ta jest zasadnicza, gdyż to właśnie utwór jest określony w ustawodawstwie jako przedmiot ochrony autorskoprawnej.

Okazuje się, że nie jest to bynajmniej sprawa oczywista. Na przykład według Tomasza Gaczyńskiego, prawnika współpracującego z Domem Spotkań z Historią, instytucją, która dysponuje jednym z największych archiwów historii mówionej w Polsce,

Relacja jako taka - czyli swobodna lub wspierana pytaniami opowieść - nie jest przedmiotem prawa autorskiego, gdyż nie jest dziełem, co z kolei wynika z faktu, iż nie jest efektem intencjonalnego działania twórczego/kreatywnego. Wplecionym elementem relacji (jako opowieści) rzeczywiście mogą być jakieś utwory - np. wiersz czy piosenka. Tylko w takim przypadku - i tylko w odniesieniu do tych elementów - można mówić o 1) konieczności pozyskania praw do rozpowszechniania i dalszego dysponowania prawami do takiego utworu i 2) konieczności formalnego przekazania prawa do korzystania z tych praw przez podmiot trzeci ${ }^{12}$.

Bardzo ogólną definicję utworu przedstawili znawcy problematyki prawnoautorskiej, Janusz Barta i Ryszard Markiewicz. Według nich utwór, to „dobro niematerialne, choć wielokrotnie zapośredniczone przez przedmioty materialne, które istnieje poprzez akty świadomości człowieka"13.

Natomiast w Ustawie o prawie autorskim i prawach pokrewnych znajdujemy następującą definicję syntetyczną utworu (art. 1 ust. 1): „przedmiotem prawa autorskiego jest każdy przejaw działalności twórczej o indywidualnym charakterze, ustalony w jakiejkolwiek postaci, niezależnie od wartości, przeznaczenia i sposobu wyrażenia (utwór)". Wśród utworów będących przedmiotem prawa autorskiego ustawodawca wylicza szczególnie interesujące dla naszego tematu dzieła (art. 1 ust. 2): w pkt 1 - wyrażone słowem, symbolami matematycznymi, znakami graficznymi (literackie, publicystyczne, naukowe, kartograficzne oraz programy komputerowe), a w pkt 9 - audiowizualne (w tym filmowe) ${ }^{14}$.

12 Taką opinię otrzymałem w korespondencji elektronicznej z przedstawicielem Domu Spotkań z Historią w Warszawie 2 VII 2018 r.

13 J. Barta, R. Markiewicz, op. cit., s. 37.

14 Ibidem. 
Kluczowe zatem jest zweryfikowanie, czy relacja oral history jest przejawem działalności twórczej o indywidualnym charakterze. Jak wyżej zostało wskazane, niektórzy prawnicy mają co do tego wątpliwości.

Zastanawiając się nad pojęciem działalności twórczej, należy skonstatować za Martą Poźniak-Niedzielską i Adrianem Niewęgłowskim, że utworem będzie rezultat takiego działania, „który choćby w minimalnym stopniu odróżnia się od innych rezultatów takiego samego działania”. Natomiast odnosząc się do interpretacji terminu „twórczość”, ci sami autorzy wskazują, że „warunkiem uznania oznaczonego świadczenia intelektualnego za utwór jest samodzielne stworzenie określonego bytu niematerialnego ustalonego w jakikolwiek sposób”15. Janusz Barta i Ryszard Markiewicz wskazują, że z twórczością mamy do czynienia, gdy rezultat działalności człowieka ma kreacyjny charakter - „istnieje subiektywnie nowy wytwór intelektu” ${ }^{16}$.

Natomiast indywidualny charakter dzieła oznacza, że musi się ono odróżniać od innych takich samych przejawów działalności twórczej w sposób świadczący o jego swoistości, oryginalności i niepowtarzalności ${ }^{17}$. Zastanawiając się nad istotą oryginalności, niektórzy badacze odwołują się do kryterium unikatowości, które zasadza się na tym, że nikt inny samodzielnie nie może stworzyć identycznego utworu ${ }^{18}$. Inni badacze zwracają uwagę, na istnienie w utworze właściwości związanych z niepowtarzalną osobowością człowieka („piętno osobiste”) ${ }^{19}$.

Utwory powinny się zatem charakteryzować dwiema cechami: nowością i oryginalnością. W tym kontekście wspomniani wyżej autorzy wyjaśniają, że „o danej działalności można powiedzieć, że jest twórcza, gdy wytwór tej działalności jest nowy co najmniej subiektywnie (nowy dla twórcy) [autor nie może stworzyć czegoś, co już jest mu znane - W.K.]. Twórczość z kolei ma indywidualny charakter, gdy rezultat tej twórczości jest nowy obiektywnie (dla odbiorców wyróżnia się spośród istniejącego zasobu utworów)”20.

Zastanówmy się zatem, czy relacja oral history według przytoczonej wyżej definicji ma znamiona utworu. Dodajmy przy tym, że w stosowanej

15 M. Poźniak-Niedzielska, A. Niewęgłowski, Wprowadzenie. Pojęcie utworu, [w:] Prawo autorskie, t. 13, red. J. Barta, Warszawa 2013, s. 9.

16 J. Barta, R. Markiewicz, op. cit., s. 49.

17 M. Poźniak-Niedzielska, A. Niewęgłowski, op. cit., s. 9.

18 Ibidem, s. 12.

19 J. Barta, R. Markiewicz, op. cit., s. 49.

2 o M. Poźniak-Niedzielska, A. Niewęgłowski, op. cit., s. 10-11. 
najbardziej powszechnie na gruncie polskim metodzie nagrywania relacji oral history silnie odciśnięte jest piętno niemieckiej metody biograficznego wywiadu narracyjnego. Jego model zakłada cztery fazy rozmowy narratora/ świadka historii z badaczem. W pierwszej narrator proszony jest o swobodną opowieść o własnym życiu. W drugim etapie badacz ma możliwość zareagowania na konkretne fragmenty usłyszanej historii, poproszenia o ich wyjaśnienie i doprecyzowanie. W trzeciej fazie jest miejsce na pytania otwarte, które są zazwyczaj przygotowane wcześniej i związane z przedmiotem/tematem prowadzonych badań. W ostatniej części można poprosić narratora o próbę podsumowania, ewentualnie wejść z nim w polemikę ${ }^{21}$. Wydaje się, że taka relacja oral history ma charakter twórczy (nowość subiektywna), gdyż obaj jej twórcy (na razie hipotetycznie) - badacz i narrator - tworzą ją podczas spotkania przez zadawanie pytań i udzielanie odpowiedzi, a jego rezultatem jest opowieść o życiu jednego z nich (zapis indywidualnego doświadczenia przeszłości). Relacja oral history ma również charakter indywidualny (nowość obiektywna), gdyż różni się od innych dóbr niematerialnych będących częścią dorobku kulturowego. Wzbogaca zatem "dziedzictwo kulturowe" o nowe dobro niematerialne. Dostrzec też w niej można „piętno osobiste” obu twórców (o czym także nieco niżej). Można zatem w przypadku relacji oral history mówić o utworze. Zawsze jest to utwór wyrażony słowem mówionym lub pokazywanym ${ }^{22}$.

Stanowisko to $\mathrm{w}$ pewnym stopniu podzielają wspomniani wyżej teoretycy prawa z Lublina, wymieniając wśród utworów „wspomnienia historycznych wydarzeń" ${ }^{23}$. Podobnie uważają wybitni prawnicy z Uniwersytetu Jagiellońskiego, Janusz Barta i Ryszard Markiewicz, zaliczając do utworów „przekazy ustne” ${ }^{24}$. Obie wspomniane formy utworów

21 P. Filipkowski, O relacjach bytych więźniów kacetów w kontekście czasu, miejsca i sytuacji powstania (albo o pożytkach z historii mówionej), „Wrocławski Rocznik Historii Mówionej", R. 2 (2012), s. 40-41.

Ośrodek „Pamięć i Przyszłość” współuczestniczył w projekcie „Historia migana” Fundacji Fonis z Wrocławia, którego celem było nagrywanie osób niesłyszących, z których część posługiwała się językiem migowym. O projekcie zob.: L. Kościelniak, E. Moroń, Historia migana - między narracją a przektadem. Uwagi metodologiczne do zbierania i opracowywania relacji osób niesłyszacych, „Wrocławski Rocznik Historii Mówionej", R. 7 (2017), s. 35-67.

24 J. Barta, R. Markiewicz, op. cit., s. 39. 
(autorzy nie przedstawią ich precyzyjnej definicji) zdają się bardzo bli-

skie temu, co chcemy nazwać relacją oral history.

Warto również zauważyć, że utwór jako dobro niematerialne istnieje niezależnie od jego materialnego nośnika (corpus mechanicum). Tak jest też w przypadku relacji, która może być zarchiwizowana na różnych nośnikach (płytach CD, DVD, przenośnych pamięciach komputerowych, serwerach itp.). Przy czym prawo autorskie mówi o utworze jako o przejawie działalności twórczej ustalonym w jakiejkolwiek postaci, przez co należy rozumieć uzewnętrznienie pozwalające na percepcję utworu przez osoby trzecie $^{25}$. Nie należy jednak utożsamiać pojęcia ustalenia utworu z pojęciem utrwalenia tegoż. Utrwalenie wszak jest jedynie jednym z rodzajów ustalenia. Ustalenie może mieć charakter jednorazowy - jest to proste zakomunikowanie dzieła „żywym słowem” - w przypadku oral history dzieje się to $\mathrm{w}$ momencie powstawania relacji. Utrwaleniem nazywamy ustalenie dzieła o charakterze trwałym, pozwalające na wielokrotne odtwarzanie treści dzieła. Nie ma przy tym znaczenia, czy chodzi o wersje materialną (egzemplarz nośnika) czy niematerialną (plik cyfrowy). W przypadku oral history mamy do czynienia z obiema formami (nośnikiem materialnym i plikami cyfrowymi nagrania). Kwestia ta jest o tyle istotna, że orzecznictwo skłania się ku konieczności ustalenia dzieła nie w jakiejkolwiek, ale w trwałej postaci.

W tym miejscu warto wrócić do kwestii, czy relacja oral history jest ze swej definicji utworem audiowizualnym. Wiadomo, że nie wszystkie relacje dokumentowane są w postaci audiowizualnej, część nagrywana jest jedynie w wersji audio, pomimo że modelowa relacja powinna być sfilmowana, aby utrwalić także komunikaty niewerbalne narratora. Istotą relacji oral history nie jest jednak jej audiowizualne utrwalenie, ale przekazanie czyjegoś autobiograficznego doświadczenia przeszłości. Forma utrwalenia jest wtórna w stosunku do istoty utworu, jakim jest relacja oral history. Odwołując się do historii badań wykorzystujących metodę oral history, można dostrzec bardzo różne formy utrwalenia tych relacji (transkrypcja, nagranie audio na taśmie magnetofonowej lub nośniku cyfrowym, nagrania audio-wideo na taśmie wideo lub nośniku cyfrowym itp.). Literatura prawnicza zwraca uwagę na relację między „sfilmowaniem” a utworem audio-

25 M. Poźniak-Niedzielska, A. Niewęgłowski, op. cit., s. 22-23. 
wizualnym ${ }^{26}$. W tym kontekście dla naszych rozważań szczególnie interesująca jest kwestia „nietwórczego utrwalenia istniejącego dzieła”27. Wydaje się, że w odniesieniu do oral history należy dostrzec istnienie dwóch bytów: relacji oral history, która jest utworem $\mathrm{w}$ rozumieniu prawa autorskiego, oraz utrwalenia w postaci rejestracji audio-wideo tego utworu. Owa rejestracja, w zależności od posiadania cechy twórczości lub nie, może być lub nie być utworem w rozumieniu prawa ${ }^{28}$. Dostrzeżmy wszak analogię do sytuacji, gdy podejrzany lub świadek jest przesłuchiwany przez policję albo sąd (w trakcie takiego przesłuchania opowiada o swojej przeszłości) i owo przesłuchanie jest rejestrowane $w$ formie audio-wideo. Nie przywiązuje się przecież w takich sytuacjach wagi do warstwy wizualnej. Kluczem jest jak najwierniejsze oddanie i udokumentowanie relacji osoby przepytywanej i trudno wówczas mówić, że owa rejestracja jest utworem audiowizualnym. Do kwestii tej wrócę w części poświęconej autorom relacji oral history.

Zdarza się także, że z jednym świadkiem historii w jakimś odstępie czasu różni badacze nagrywają relacje oral history. $Z$ taką sytuacją mamy na przykład do czynienia w zbiorach Ośrodka „Pamięć i Przyszłość”, w których znajdują się między innymi dwie relacje nagrane z Wandą Kiałką - pierwsza przeprowadzona w 2007 r. przez Mateusza Kotwicę (o długości nagrania $2 \mathrm{~h} 42 \mathrm{~min})^{29}$, a druga przeprowadzona w $2010 \mathrm{r}$. przez Annę Jajor-Morawiec (3 h $36 \mathrm{~min})^{30}$. Czy zatem obie te relacje będą utworami w rozumieniu polskiego prawodawstwa? W mojej opinii tak. Spełniają wszak przytoczoną powyżej definicję utworu. Mimo że ta sama osoba dwukrotnie opowiada o swoim życiu, zatem potencjalnie i w jakimś zakresie tę samą historię, to różne okoliczności (czas, osoba badacza, miejsce), w jakich rejestruje się relację, sprawiają, że powstaje odmienna w swej warstwie semantycznej i treściowej ${ }^{31}$, przynajmniej w pewnym stopniu, opowieść. Owe okoliczności zyskują jeszcze na znaczeniu wraz z odstępem czasu, jaki dzieli oba wywiady.

26 J. Barta, R. Markiewicz, op. cit., s. 312.

27 Ibidem.

28 Ibidem, s. 313.

29 Archiwum Ośrodka „Pamięć i Przyszłość” (dalej: AOPiP), sygn. AHM-82, Relacja Wandy Kiałki, 11 XI 2007 r. (sporządził: Mateusz Kotwica).

3o AOPiP, sygn. AHM-83, Relacja Wandy Kiałki, 25 V 2010 r., 7 VII 2010 r. (sporządziła: Anna Jajor-Morawiec).

31 Na marginesie rozważań dodajmy, że ochronie prawnej podlega forma utworu, a nie jego treść. 

ośmiu osób, ocalałych z Holokaustu, zdublowane po 25 latach (nagrane przez tego samego badacza). Badacze zauważyli, że z czasem zmienia się świadomość tematu, o którym opowiadali ich rozmówcy (w tym przypadku chodziło o Holokaust) i zdolność relacjonowania przeszłości, co wynika ze znajdowania się na innym etapie życia. Dostrzeżono także wpływ na narrację, jaki miały zmiany w technice nagrywania wywiadu, warsztacie badawczym i przyjętej metodologii ${ }^{32}$. Ten ostatni aspekt niezwykle trafnie opisał również Piotr Filipkowski, porównując relacje byłych więźniów niemieckich obozów Auschwitz i Mauthausen stworzone przez Muzeum Auschwitz i później przez badaczy w ramach "Mauthausen Survivors Documentation Project”. Filipkowski obok powtarzalnych fragmentów dotyczących szczególnie faktografii związanej z obozowym życiem wskazał na znaczące różnice pomiędzy relacjami tych samych osób, zarejestrowanymi w odstępie czasu, które wiązał z metodą, jakiej użyto przy przeprowadzaniu wywiadu, oraz z podejściem danego badacza do tego źródła (relacji oral history) ${ }^{33}$. W obu zatem sytuacjach: gdy wywiadu udzielał ten sam świadek różnym badaczom, a nawet gdy w wywiadach uczestniczyły te same osoby, powstały odmienne utwory. Z perspektywy prawnej pojawia się jeszcze problem stopnia odmienności obu relacji, który wystarcza do uznania ich za osobne utwory. W tej kwestii konieczne będą jednostkowe decyzje dotyczące konkretnych sytuacji. Przy czym teoria prawa podpowiada pewne ogólne rozstrzygnięcia. Nawet jeśli w dwóch (czy większej ilości) zarejestrowanych relacjach tej samej osoby znajdują się podobieństwa, można odwołać się do doktryny kleine Münze (drobnych monet), która głosi, że utwór podlega ochronie, jeśli choćby w niewielkim stopniu odróżnia się od innych dzieł ${ }^{34}$. Warto przy tym zauważyć, że wśród prawników toczy się dyskusja na temat tej teorii, która ostatecznie sprowadza się do określenia, jak duże muszą być różnice między wytworami „ludzkiej kreatywności”, aby nadać im status utworu objętego ochroną prawnoautorską ${ }^{35}$. $z$ Holokaustu, „Wrocławski Rocznik Historii Mówionej”, Wydanie Specjalne (2018), S. 239-241.

33 P. Filipkowski, op. cit., s. 37-71.

34 M. Poźniak-Niedzielska, A. Niewęgłowski, op. cit., s. 14-15.

35 Ibidem, s. 16. 
Zacznijmy od ogólnego wprowadzenia pojęć autor i autorstwo. Autor jest pojęciem wieloznacznym. W Słowniku języka polskiego znajdujemy dwie definicje pojęcia autor: węższe - twórca dzieła literackiego, naukowego, dzieła sztuki, dzieła technicznego (wynalazku, projektu), i szersze - sprawca, inicjator, projektodawca ${ }^{36}$. Nie wchodząc w tym miejscu w wieloznaczne potoczne stosowanie tego terminu oraz jego funkcjonowanie w naukach humanistycznych, zastanówmy się, jak pojęcie to funkcjonuje w obszarze literatury prawniczej. Warto przy tym zauważyć, że w polskich ustawach spotyka się głównie termin „twórca”, który, jak wskazują badacze, zaczerpnięty został z języka potocznego ${ }^{37}$.

Termin „twórca”, co ciekawe, od pierwszej polskiej ustawy o prawie autorskim z 1926 r. do ostatniej ustawy z 1994 r., nie doczekał się definicji legalnej, ale funkcjonuje w ścisłym powiązaniu z terminem „utwór”38, którego definicję przedstawiliśmy powyżej. Za twórcę w rozumieniu ustawy należy zatem uznać osobę, której utwór spełni określone w powyższej definicji przesłanki. Jakie są zatem relacje między terminem twórca i terminem autor? Nie wchodząc tu w zawiłości dyskusji prawniczych, przyjmuję za wywodem Marleny Jankowskiej, że pojęcia te w rozumieniu obecnie funkcjonującego prawa należy uważać za synonimiczne. W takim właśnie znaczeniu pojęcie autor pojawia się w Ustawie o prawie autorskim w art. $17^{1} \mathrm{i}$ art. $36^{39}$. Dodajmy także, że w rozumieniu prawniczym twórcą może być jedynie osoba fizyczna, a ponieważ z powstaniem utworu nie wiąże się składanie jakichkolwiek oświadczeń woli, prawnie obojętne pozostają wszelkie przymioty dotyczące twórcy, takie jak wiek, stan ubezwłasnowolnienia, stan psychiczny oraz obywatelstwo, płeć, rasa, religia i język ${ }^{40}$. Podsumowując tę część, zacytuję wspomnianą Marlenę Jankowską, że „status twórcy nabywa się z chwilą powstania utworu, czyli wówczas, gdy osoba ta powołała do życia co najmniej jeden jego element twórczy w postaci zdatnej do percepcji przez inną osobę"41.

Stownik języka polskiego, red. M. Szymczak, t. 1, Warszawa 1982, s. 101-102.

M. Jankowska, Autor i prawo do autorstwa, Warszawa 2011, s. 328.

Ibidem.

Ibidem, s. 330-332.

Ibidem, s. 334 .

Ibidem, s. 335, autorka odwołuje się do pracy R.M. Sarabińskiego, Utwór fotograficzny i jego twórca w polskim prawie, Kraków 2004, s. 206. 
Pojęcie autorstwa jest natomiast ściśle powiązane $\mathrm{z}$ terminem autor i także może mieć wiele potocznych znaczeń. Dla dalszego wywodu przyjmujemy, że autorstwo to czyn o twórczym charakterze. Cytując literaturę prawniczą, ,autor dokonuje swoim zachowaniem zmiany w świecie fizykalnym, a rezultat twórczej działalności zostaje objęty ochroną autorskoprawną przy spełnieniu przesłanek wymaganych ustawą"; podkreśla się przy tym warunek, by w utworze móc odnaleźć „osobistą autorską obecność”42.

W literaturze brak jednoznacznego określenia, kto jest twórcą/autorem relacji oral history. Ze standardów amerykańskiego Oral History Association wynika, że właścicielem praw autorskich do relacji jest świadek historii ${ }^{43}$. Tak traktują świadka historii i niektórzy polscy oraliści, np. Wiktoria Kudela-Świątek ${ }^{44}$. Natomiast np. Franka Maubach, analizując przemiany w biograficznych badaniach historycznych w Niemczech, z pewną krytyką wskazywała, że „wytwórcami” (Produzenten) „wspomnień świadków historii są zarówno dziennikarze, jak i historycy, uczestnicy warsztatów historycznych czy osoby pracujące w miejscach pamięci", zatem osoby przeprowadzające yywiady $^{45}$. Samej autorce chyba nieco bliżej do poglądu, że oral history to wspólne pisanie historii przez badacza i jego rozmówcę ${ }^{46}$. Także Marta Kurkowska-Budzan, odwołując się do dyskusji na forum PTHM, stwierdziła, że w polskiej praktyce badawczej „najczęściej przyjmuje się, że prawa autorskie do wywiadu posiada badacz - tak jak w przypadku wywiadu dziennikarskiego"47. W związku z brakiem precyzyjnych przepisów autorskoprawnych dotyczących oral history, spójrzmy per analogiam, jak interpretowane są kwestie autorstwa w odniesieniu do wywiadu dziennikarskiego.

Dla przykładu Igor Borkowski w odniesieniu do dziennikarza używa zazwyczaj pojęcia autor ${ }^{48}$. Analizując relację między dziennikarzem i jego

42 Ibidem, s. 100.

43 M. Kurkowska-Budzan, op. cit., s. 29.

44 W. Kudela-Świątek, Nieznośny ciężar przekazu, czyli o przekładzie źródeł mówionych w badaniach oral history, „Wrocławski Rocznik Historii Mówionej”, R. 2 (2012), s. 9, 12.

45 F. Maubach, Świadek historii. Swobodne wspominanie a krytyka źródta historycznego - o ambiwalencji metody w zachodnioniemieckiej oral history okoto roku 1980 , „Wrocławski Rocznik Historii Mówionej”, R. 3 (2013), s. 44.

46 Ibidem, s. 68.

47 M. Kurkowska-Budzan, op. cit., s. 29.

48 I. Borkowski, Wspótczesny prasowy wywiad dziennikarski: techniki prowadzenia, opracowanie, publikacja, „Wrocławski Rocznik Historii Mówionej”, R. 1 (2011), s. 59, $61,62,65$. 
rozmówcą pod względem komunikacyjnym, dostrzega, że to rozmówca, „jako znawca tematu czy dysponent własnej biografii”, ma przewagę nad dziennikarzem, ale „moc komunikacyjna w większej mierze przypisana jest dziennikarzowi - jako znającemu z góry choćby zarys przebiegu rozmowy, autorowi pytań, które podczas spotkania padną, późniejszemu redaktorowi całości" ${ }^{49}$. Autorstwo rozmówcy pojawia się w momencie analizy zagadnienia autoryzacji tekstu. Wówczas rozmówca uzyskuje status „autora wypowiadanych, a następnie przez dziennikarza zapisywanych i porządkowanych słów"50. Podobnie Marek Safjan jednoznacznie wskazuje, że autorskie prawa majątkowe do wywiadu przysługują dziennikarzowi, gdyż on wywiad pisze, on określa jego zakres i pytania ${ }^{51}$. Niektórzy inni badacze wskazują, że wywiad dziennikarski ma dwóch autorów i są nimi obaj bezpośredni uczestnicy $^{52}$. Natomiast raczej odrzuca się wyłączne autorstwo rozmów$\mathrm{cy}^{53}$. Na marginesie należy dodać, że w przypadku dziennikarzy mamy do czynienia z wyjątkową sytuacją̆, gdyż zakres ich działalności regulowany jest odrębną ustawą ${ }^{54}, \mathrm{w}$ której zresztą w kilku miejscach obok pojęcia dziennikarza ustawodawca używa określenia „autor materiału prasowego”, i nie jest jasna relacja między tymi pojęciami (art. 15) ${ }^{55}$. Pewne światło na kwestię autorstwa wywiadu dziennikarskiego rzuca wyrok polskiego Sądu Najwyższego z dnia 22 września 1971 r., II CR 330/71, dotyczący reportażu. Według sądu „z istoty utworu literackiego będącego reportażem wynika, że jego twórcą jest ten, kto zebrał i opracował materiał będący przedmiotem reportażu. Nie jest natomiast współtwórcą w rozumieniu art. $11 \mathbb{1} 1 \mathrm{pr}$. autorskiego ten, kto dostarczył materiału do takiego utworu. W szczególności dotyczy to także osoby, która w rozmowach z reporterem, utrwalonych na taśmie magnetofonowej, opowiedziała mu o wydarzeniach ze swego życia,

\section{西} Warszawa 1999; B. Michalski, Podstawowe problemy prawa prasowego, Warszawa 1998.

Ibidem, s. 65 .

Ibidem, s. 76 .

J. Kralka, Komu przystuguja prawa autorskie do wywiadu?, „Prawo Nowych Technologii”, http://techlaw.pl/komu-przysluguja-prawa-autorskie-wywiadu/ (dostęp: 9 IX 2014 r.).

M. Kita, Wywiad prasowy. Język - gatunek - interakcja, Katowice 1998, s. 100 i nn.

J. Kralka, op. cit.

Większość prawników wskazuje, że obecnie obowiązująca ustawa jest bardzo niedoskonała i wymaga pilnej zmiany, zob.: J. Sobczak, Ustawa prawo prasowe. Komentarz, Ustawa z dnia 26 stycznia 1984 r. Prawo prasowe (tekst jedn.: Dz.U. 2018 poz. 1914). 
chociażby opowieść jej stała się następnie zasadniczą treścią reportażu. W takim bowiem wypadku także osoba ta staje się obiektem reportażu". Teza powyższa oznacza, że jedynym autorem reportażu, - chyba według Sądu Najwyższego - wywiadu dziennikarskiego, jest dziennikarz. Treść tego wyroku poddawana była jednak poważnej krytyce, zwłaszcza że reportaż zawierał liczne elementy wywiadu ${ }^{56}$. Andrzej Kopff zakwestionował zasadność uznania dziennikarza za jedynego autora reportażu, który był przedmiotem sporu. Reportaż ów oparty był na rozmowach z więźniem nagranych na taśmę magnetofonową. Osadzony opowiadał dziennikarzowi o swoim życiu od dzieciństwa aż po dzień skazania. Reporter zaś zadawał pytania naprowadzające rozmówcę na temat. Dziennikarz we wstępie do publikacji stwierdził, że dokonał pewnych skrótów wypowiedzi, uzupełnił je o relację żony skazanego oraz określił układ całości, lecz nie ingerował w język, zachował oryginalny styl rozmówców. Natomiast więzień twierdził, że jego opowieść nie była tylko podaniem faktów, ale zawierała cechy indywidualne, gdyż dzięki swojej fantazji i umiejętności percepcji tworzył on narrację zawierającą także doświadczenia innych więźniów. Według Kopffa działania reportera (dokonanie wyboru i układ wypowiedzi) uzasadniają jedynie uznanie go za współtwórcę utworu ${ }^{57}$.

Mimo pewnych podobieństw relacja oral history różni się znacząco od wywiadu dziennikarskiego. W przypadku tego drugiego zazwyczaj nad biografią narratora dominuje temat. W takiej sytuacji wkład autorski dziennikarza jest bardzo wyraźny przez określenie właśnie tematu wywiadu, zdefiniowanie interesujących zagadnień itp. Nawet jeśli dziennikarz przeprowadza wywiad biograficzny, wyraźnie ogranicza go swoimi pytaniami. Zazwyczaj narrator nie ma swobody w sposobie komunikowania opowieści o swoim życiu. W przypadku relacji oral history ten element jest natomiast kluczowy.

Hipotetycznie, na potrzeby dalszego wywodu, można wyobrazić sobie sytuację, w której badacz zwraca się do rozmówcy: „proszę opowiedzieć mi historię swojego życia"58, po czym następuje kilkugodzinna swobodna wypowiedź autobiograficzna. Trudno uznać pytanie badacza za twórcze, o indywidualnym charakterze. Na marginesie należy dodać, że nie ma tu znaczenia cel badawczy, gdyż w rozumieniu prawa autorskiego nieistotna jest celowość

56 M. Szaciński, Reportaż w Prawie autorskim, „Palestra”, t. 41 (1997), nr 6-7, s. 6.

57 Ibidem, s. 7.

58 P. Filipkowski, op. cit., s. 40. 
powstania utworu ${ }^{59}$. Na pierwszy rzut oka wydaje się, że nie można uznać takiego badacza za współautora. A jednak w trakcie tak przeprowadzonego (czy zainicjowanego) wywiadu badacz, jak mówią oraliści, aktywnie słucha, potakuje, niewerbalnie zachęca świadka do tego, by kontynuował opowieść. W jakimś sensie jego obecność wpływa na kształt relacji. Badacz - powiedzmy również otwarcie - cały czas też ją kontroluje, sporządza notatki, aby wrócić do pewnych wątków, jeśli nie zostaną wyczerpane. Bez wątpienia należy zauważyć, że jego obecność jest warunkiem koniecznym, aby relacja w ogóle powstała. Bez niego ów utwór, jeśli się zgodzimy nadać taki status relacji, na pewno nie mógłby zaistnieć. Dodajmy, że badacze są zgodni, iż relacja oral history ma charakter dialogiczny i powstaje w wyniku interpersonalnej interakcji. Czy zatem badacz jest współautorem? Wydaje się, że w tym przypadku rozstrzygająca może być weryfikacja, czy jego działania miały znamiona twórczej działalności o indywidualnym charakterze - wszak orzecznictwo stoi na stanowisku, że źródło inspiracji, stopień wysiłku intelektualnego i ilość czasu poświęcona na tworzenie utworu nie mają wpływu na zaliczenie danego rezultatu intelektualnego $w$ poczet utworów ${ }^{60}$. Zastrzeżmy jednocześnie, że powyższa uwaga ma jedynie czysto teoretyczny charakter, gdyż w praktyce nie spotykamy relacji oral history, w których udział badacza ograniczyłby się do zadania jednego konwencjonalnego pytania. Zawsze, jak już wyżej zostało wspomniane, relacja oral history zawiera także pozostałe fazy wywiadu, w których wkład autorski badacza jest znaczący.

Warto w tym miejscu zatem zastanowić się, czy w przypadku relacji oral history można odwołać się do pojęcia współtwórczości, analogicznie do tego, co proponował Andrzej Kopff, analizując wspomniany wyżej wyrok Sądu Najwyższego z 1972 r. dotyczący reportażu. Na takie rozwiązanie, choć nie w prawniczym sensie, wskazywał Alessandro Portelli: „The final result of the interview is the product of both the narrator and the researcher" 61. Większość badaczy prawa przyjmuje, że podstawowym kryterium uznania danej osoby za współtwórcę jest wniesienie twórczego wkładu we wspólne dzieło $w$ procesie powstania utworu ${ }^{62}$. Istotne jest zatem rozważenie ról osób biorących udział w powstawaniu utworu. Oznacza to, że nie tylko

59

60

61

$$
\text { , }
$$

M. Jankowska, op. cit., s. 335.

M. Poźniak-Niedzielska, A. Niewęgłowski, op. cit., s. 20.

A. Portelli, What makes oral history different, [w:] The oral history reader, red.

R. Perks, A. Thomson, b.m. 2003, s. 71.

62 J. Banasiuk, Wspóttwórczość i jej skutki w prawie autorskim, Warszawa 2012, s. 111. 
efekt twórczej współpracy, ale także pojedynczy wkład w utwór powinien mieć charakter twórczy i indywidualny ${ }^{63}$. Jednocześnie podstawą działania współtwórców powinno być porozumienie dotyczące stworzenia jednego dzieła. Zakłada się przy tym, że twórcom powinna towarzyszyć świadomość wspólnego celu, jakim jest stworzenie wspólnego utwor ${ }^{64}$.

W naszym przypadku, wydaje się, oba te warunki występują. To znaczy każdy z uczestników powstawania relacji oral history ma swój twórczy wkład w jej tworzenie - badacz przez wywołanie wspomnień oraz wpływ na przebieg narracji, zadawanie pytań i podtrzymywanie opowieści, narrator przez samą opowieść, cytując za literaturą prawniczą, przez „twórcze ukształtowanie przeżyć i wyznań" ${ }^{65}$. Zalecenia etyczne przyjęte zasadniczo w praktyce badawczej podkreślają, że rozmówca powinien udzielić świadomej zgody na wywiad i jego wykorzystanie w określonych wcześniej celach $^{66}$. Praktykę tę można uznać za wymagane prawem porozumienie stron odnośnie do powstania działa. Warto w tym miejscu dostrzec, że w doktrynie prawnej wyróżnia się utwory współautorskie rozłączne i nierozłączne, a każda z tych kategorii pociąga za sobą inne konsekwencje prawne. Utwory współautorskie rozłączne to takie, w których można wyodrębnić i przypisać różnym autorom poszczególne części, mające samodzielne znaczenie ${ }^{67}$. Za nierozłączne uważa się dzieła jednolite, w których poszczególne autorskie wkłady nie nadają się do samodzielnej eksploatacji ${ }^{68}$. Analizując wywiad biograficzny jako utwór, nie jest prosto zakwalifikować go do jednego rodzaju dzieła. Wszak z jednej strony można oddzielić pytania badacza od odpowiedzi rozmówcy i traktować je odrębnie, lecz z drugiej często (zależy to od założeń badawczych) zestawienie pytań i odpowiedzi jest kluczowe przy interpretacji relacji. Sprawa komplikuje się jeszcze bardziej, gdy weźmiemy pod uwagę "produkt” wywiadu biograficznego w postaci nagrania audio lub audio-wideo. Podobnie jest w przypadku utworów audiowizualnych, które określane są jako hybrydy, posiadające zarówno cechy utworu współautorskiego rozłącznego, jak i nierozłącznego ${ }^{69}$.

\footnotetext{
63 Ibidem, s. 112.

64 Ibidem, s. 123.

65 Ibidem, s. 116.

66 M. Kurkowska-Budzan, op. cit., s. 29.

67 J. Banasiuk, op. cit., s. 165-167.

68 Ibidem, s. 169.

69 Ibidem, s. 171.
} 
Pewną kwestią do rozstrzygnięcia w przypadku utworów audiowizualnych jest także rola operatora kamery. Jest to o tyle warte dostrzeżenia, że $\mathrm{w}$ nowelizacji z $2000 \mathrm{r}$. ustawy Prawo autorskie w rozdziale $6 \mathrm{w}$ art. $69 \mathrm{roz}-$ szerzono katalog twórców utworu audiowizualnego o „operatora obrazu”. Oznacza to, że ustawodawca szczególnie dostrzegł wkład tego twórcy w powstanie utworu audiowizualnego ${ }^{70}$. Przypomnijmy, że w niniejszym wywodzie opowiadamy się za odróżnieniem relacji oral history od jej „utrwalenia" poprzez sfilmowanie. Jak wyżej wspomniałem, w praktyce badań oral history filmowanie zazwyczaj traktowane jest jako czysto techniczna metoda rejestracji wywiadu. Rola operatora kamery ogranicza się wówczas do technicznej obsługi urządzenia, włączania i wyłączania, oraz ustalenia kadru zgodnie z przyjętymi zasadami. Wydaje się, że nie będziemy mieli wówczas do czynienia z utworem, a zatem i ze współtwórcą. Zdarza się jednak, że operator kamery (czasem kamerę obsługuje badacz prowadzący wywiad, a czasem jest to osoba trzecia) ma swój twórczy wkład w powstanie zapisu relacji (zmienia kadrowanie, dokonuje zbliżeń, wybiera tło, stara się określić oświetlenie itp.). Nie jest to jednak łatwe do rozgraniczenia. Można przyjąć, że osoba obsługująca kamerę zawsze dokonuje szeregu wyborów dotyczących kadru, oświetlenia itp. Czasem jednak robi to intuicyjnie, bez zastanowienia się, np. w sytuacji gdy operator kamery „decyduje” się na filmowanie bez ingerowania $\mathrm{w}$ światło (światło zastane), zgodnie z przyjętą konwencją ustawia kamerę naprzeciwko świadka historii, tak aby jego głowa była w centrum kadru, następnie włącza kamerę i po kilku godzinach wyłącza. Czy można tutaj mówić o twórczym wkładzie o indywidualnym charakterze?

Konkludując, należy stwierdzić, że relacja oral history ma dwóch autorów: badacza i świadka historii (kolejność bez znaczenia). Współautorem może być także osoba filmująca wywiad, nie jest tak jednak zawsze.

\section{Autorskie prawa osobiste i autorskie prawa majątkowe do relacji}

W tym miejscu warto skrótowo zreferować treść prawa autorskiego. Ustawa z 1994 r. rozróżnia prawa autorskie osobiste, prawa autorskie majątkowe i prawa pokrewne. W niniejszym artykule przedstawię jedynie autorskie prawa osobiste i w mniejszym zakresie autorskie prawa majątkowe. Autorskie prawa osobiste zgodnie z art. 16 ustawy „chronią nieograniczoną 
w czasie i nie podlegającą zrzeczeniu się lub zbyciu więź twórcy z utworem". W pięciu podpunktach tego artykułu ustawodawca precyzuje zakres owej ochrony, to znaczy prawo do: 1) autorstwa; 2) oznaczenia utworu swoim nazwiskiem, pseudonimem lub udostępnienia go anonimowo; 3) nienaruszalności treści i formy; 4) decydowania o pierwszym udostępnieniu; 5) nadzoru nad sposobem korzystania. Ustawodawca poprzedza ten katalog sformułowaniem „w szczególności”, co może oznaczać, że nie jest to lista zamknięta $^{71}$. Istotnym zagadnieniem praw autorskich osobistych jest obowiązek wskazania twórcy niezależnie od rodzaju jego oznaczenia ${ }^{72}$.

Natomiast prawa autorskie majątkowe opisane w wielu artykułach ustawy dotyczą uprawnień twórcy, ze szczególnym uwzględnieniem kwestii ekonomicznych. Ogólnie art. 17 ustawy określa je w następujący sposób: „twórcy przysługuje wyłączne prawo do korzystania z utworu i rozporządzania nim na wszystkich polach eksploatacji oraz do wynagrodzenia za korzystanie z utworu".

Jak wyżej przyjęliśmy, relacja oral history ma dwóch autorów: badacza i rozmówcę (kolejność bez znaczenia). Komu zatem i w jakim zakresie przysługują prawa autorskie?

Zgodnie z art. 9 ustawy współtwórcom przysługuje prawo autorskie wspólne i domniemywa się, że wielkości udziałów są równe, choć każdy z twórców może żądać określenia wielkości udziałów przez sąd ${ }^{73}$. Jak zatem interpretować ten zapis w odniesieniu do autorskich praw osobistych, szczególnie w kwestii oznaczania utworu nazwiskiem autora? Kluczowym zagadnieniem jest rozstrzygnięcie, czy prawa osobiste podlegają wspólności, czy przynależą każdemu współtwórcy osobno. Jak referuje Joanna Banasiak, w polskiej doktrynie prawnej przeważa stanowisko, że prawa autorskie osobiste nie podlegają wspólności ${ }^{74}$. Oznacza to, że współtwórcy przystępując do pracy na dziełem, muszą uwzględnić specyfikę danego dzieła, z której może wynikać uszczuplenie ich praw przez konieczność respektowania uprawnień pozostałych twórców ${ }^{75}$. W analizowanym przez nas przypadku przy oznaczaniu dzieła nazwiskami twórców wydaje się słuszne wskazanie zakresu ich udziału. Z takiego zapisu powinno wynikać,

\footnotetext{
71 M. Jankowska, op. cit., 361, 368-369.

72 Ibidem, S. 382-395.

73 Dz.U. 1994 nr 24 poz. 83, art. 9.

74 J. Banasiak, op. cit., s. 242 i nn.

75 Ibidem, s. 252.
} 
kto zadawał pytania, a kto odpowiadał. Takie respektowanie autorskich praw osobistych odnajdujemy w normie PN-ISO 690: 2002: Dokumentacja - Przypisy bibliograficzne - Zawartość, forma i struktura, według której zapis bibliograficzny wywiadu powinien mieć następujący układ: imię i nazwisko osoby udzielającej wywiadu, tytuł wywiadu, po słowach rozmowę przeprowadził - imię i nazwisko osoby prowadzącej wywiad.

Natomiast w odniesieniu do praw autorskich majątkowych w przypadku utworów współautorskich można posługiwać się terminem „wspólność". Dodatkowo z art. 9 ust. 5 wynika, że do autorskich praw majątkowych przysługujących współtwórcom stosuje się przepisy kodeksu cywilnego o współwłasności w częściach ułamkowych. Przy czym zgodnie z art. 9 ust. 3 ustawy do wykonywania prawa autorskiego do całości utworu potrzebna jest zgoda wszystkich jego współtwórców. W razie jej braku każdy ze współtwórców może żądać rozstrzygnięcia przez sąd. Oznacza to, że wszelkie umowy rozporządzające, licencje i faktyczne korzystanie z utworu wymagają zgody wszystkich współtwórców. W tym miejscu warto wrócić do kwestii określenia relacji oral history jako utworu współautorskiego rozłącznego lub nierozłącznego. W przypadku utworów rozłącznych w art. 9 ust. 2 ustawodawca, oprócz prawa do całości dzieła, przyznaje każdemu współtwórcy prawa autorskie do jego części, mającej samodzielne znaczenie, przy czym warunkuje to brakiem uszczerbku dla praw współtwórców. Zatem w naszym przypadku oznaczałoby to, że badacz dysponuje prawami autorskimi np. do kwestionariusza pytań, a jego rozmówca do opowieści ${ }^{76}$. Podstawową kwestią będzie tu ustalenie, czy te części składające się na utwór mają samodzielne znaczenie. Niezależnie od tego generalnym wymogiem do rozporządzania relacją jest zgoda obu współtwórców.

\section{Praktyka archiwów historii mówionej}

$\mathrm{Na}$ koniec poddałem analizie treści oświadczeń (deklaracji) składanych przez narratorów/świadków historii na rzecz Muzeum Powstania Warszawskiego, Domu Spotkań z Historią/Fundacji Ośrodka KARTA, Ośrodka „Brama Grodzka - Teatr NN” i Ośrodka „Pamięć i Przyszłość"77. Na wstępie muszę zaznaczyć, że nie jestem pewien, w jakim celu w każdej

76 M. Jankowska, op. cit., s. 191-199.

77 Wykorzystałem formularze oświadczeń przesłane mi pocztą elektroniczną przez pracowników wyżej wymienionych instytucji w 2014 r. 
instytucji pobierane jest owo oświadczenie. Zważywszy na powyższą opinię prawnika współpracującego DSH, nie musi być nim zabezpieczenie związane z prawem autorskim. Niemniej w każdym z tych oświadczeń mogę dopatrzyć się odniesienia (nie zawsze wprost) do praw autorskich. Z treści tych dokumentów wynika, że wszystkie te instytucje uważają narratora za autora relacji, choć nie nazywają go w ten sposób. Także w żadnym $\mathrm{z}$ analizowanych dokumentów nie posłużono się wprost pojęciem praw autorskich, choć treść oświadczeń wskazuje, że to narrator dysponuje autorskimi prawami majątkowymi do relacji. Wszystkie oświadczenia używają sformułowania „wyrażam zgodę na wykorzystanie relacji”, co oznaczać ma, że mamy do czynienia z licencją. Po tym sformułowaniu następuje katalog pól eksploatacji, przy czym tylko w oświadczeniach Muzeum Powstania Warszawskiego i Ośrodka „Pamięć i Przyszłość” odwołano się do katalogu $\mathrm{z}$ art. 50 ustawy. Warto tu nadmienić, że zgodnie z art. 41 ust. 2 ustawy umowa licencyjna odnosi się tylko do pól eksploatacji w niej wymienionych, zatem jest to element konieczny licencji ${ }^{78}$. Niektóre analizowane oświadczenia zawierają także zgodę narratora na wykorzystanie jego wizerunku przez poszczególne instytucje, co wypełnia zobowiązanie wynikające z art. 81 ustawy. W żadnym z oświadczeń nie pojawia się wprost kwestia współautorstwa. W oświadczeniu Ośrodka „Brama Grodzka” użyto w odniesieniu do świadka historii sformułowania, że „złożył on ustną relację”, zaś odnośnie do badacza, że „relacja została zarejestrowana przez...”. Natomiast w oświadczeniu Ośrodka KARTA świadek historii stwierdza: „relację przekazałem” „działającemu na rzecz Fundacji Ośrodka KARTA” badaczowi. W oświadczeniu Ośrodka "Pamięć i Przyszłość” odróżniono świadka historii od „osoby sporządzającej świadectwo”. Natomiast w oświadczeniu Muzeum Powstania Warszawskiego nie ma żadnej informacji o osobie, które rozmawiała ze świadkiem historii. Niestety nie wiem, czy wymienione instytucje zawierają umowy licencyjne z badaczami przeprowadzającymi wywiady jako współautorami utworu. W Ośrodku „Pamięć i Przyszłość” wprowadzono praktykę podpisywania umów o dzieło z osobami sporządzającymi relacje, które nie są pracownikami instytucji. Umowa taka nie jest wymagana, jeżeli osoba przeprowadzająca wywiad jest zatrudniona

78 J. Barta, R. Markiewicz, Obowiq̨zek wymienienia pól eksploatacji w umowie licencyjnej, http://www.lex.pl/akt/-/akt/obowiazek-wymienienia-pol-eksploatacji-w-umowie-licencyjnej (dostęp: 10 IX 2014 r.). 
w danej instytucji, gdyż zgodnie z art. 12 ustawy, „pracodawca, którego pracownik stworzył utwór w wyniku wykonywania obowiązków wynikających ze stosunku pracy, nabywa $\mathrm{z}$ chwilą przyjęcia utworu autorskie prawa majątkowe”. Zapewne jednak dość często relacje nagrywane są przez badaczy, którzy nie są zatrudnieni w danej instytucji. O tym, że wszystkie te instytucje mają świadomość, że także badacze są współautorami relacji, świadczy opis poszczególnych relacji w ich katalogach archiwalnych, w których autorskie prawo osobiste badaczy, to znaczy prawo do oznaczenia utworu imieniem i nazwiskiem, jest poszanowane ${ }^{79}$. Warto tu dodać, że w katalogach relacji Ośrodka „Brama Grodzka - Teatr NN” z Lublina narrator wprost nazywany jest autorem, a badacz współtwórcą.

Podsumujmy, że w przypadku relacji oral history mamy do czynienia $\mathrm{z}$ utworem $\mathrm{w}$ rozumieniu prawa autorskiego oraz ze współautorstwem świadka historii i badacza, których wkład w powstanie relacji (utworu) powinien być odpowiednio zaznaczany w opisach bibliograficznych. Taka praktyka w zasadzie funkcjonuje. Jednocześnie obaj twórcy dysponują autorskimi prawami majątkowymi do relacji. Wydaje się, że to prawo - szczególnie wobec badacza - nie zawsze jest dostrzegane przez instytucje archiwizujące relacje. 
Banasiuk J., Wspóttwórczość i jej skutki w prawie autorskim, Warszawa 2012.

Barta J., Markiewicz R., Obowiazek wymienienia pót eksploatacji w umowie licencyjnej, http:// www.lex.pl/akt/-/akt/obowiazek-wymienienia-pol-eksploatacji-w-umowie-licencyjnej (dostęp: 10 IX 2014 r.).

Barta J., Markiewicz R., Prawo autorskie, Warszawa 2016.

Borkowski I., Wspótczesny prasowy wywiad dziennikarski: techniki prowadzenia, opracowanie, publikacja, „Wrocławski Rocznik Historii Mówionej”, R. 1 (2011), s. 57-79.

Filipkowski P., O relacjach byłych więźniów kacetów w kontekście czasu, miejsca i sytuacji powstania (albo o pożytkach $z$ historii mówionej), „Wrocławski Rocznik Historii Mówionej”, R. 2 (2012), s. 37-71.

Jankowska M., Autor i prawo do autorstwa, Warszawa 2011.

Kierzkowski M., Historia mówiona - próba definicji pojęcia, „Wrocławski Rocznik Historii Mówionej", R. 4 (2014), s. 5-20.

Kita M., Wywiad prasowy. Język - gatunek - interakcja, Katowice 1998.

Kościelniak L., Moroń E., Historia migana - między narracją a przekładem. Uwagi metodologiczne do zbierania i opracowywania relacji osób niestyszacych, „Wrocławski Rocznik Historii Mówionej", R. 7 (2017), s. 35-67.

Kralka J., Komu przystuguja prawa autorskie do wywiadu?, „Prawo Nowych Technologii”, http:// techlaw.pl/komu-przysluguja-prawa-autorskie-wywiadu/ (dostęp: 9 IX 2014 r.).

Kudela-Świątek W., Nieznośny ciężar przekazu, czyli o przektadzie źródeł mówionych w badaniach oral history, „Wrocławski Rocznik Historii Mówionej”, R. 2 (2012), s. 5-35.

Kurkowska-Budzan M., Informator, świadek historii, narrator - kilka wątków epistemologicznych i etycznych oral history, „Wrocławski Rocznik Historii Mówionej”, R. 1 (2011), s. 9-34.

Laub D., Bodenstab J., Dwadzieścia pięć lat później. Powrót do świadectw ocalałych z Holokaustu, „Wrocławski Rocznik Historii Mówionej”, Wydanie Specjalne (2018), s. 239-255.

Lewandowska I., Źródła oralne w warsztacie badawczym historyka dziejów najnowszych $i$ w edukacji historycznej, [w:] Źródła w edukacji historycznej. III Toruńskie Spotkania Dydaktyczne, red. S. Roszak, M. Strzelecka, A. Wieczorek, Toruń 2006, s. 155-161.

Maubach F., Świadek historii. Swobodne wspominanie a krytyka źródła historycznego - o ambiwalencji metody w zachodnioniemieckiej oral history około roku 1980, „Wrocławski Rocznik Historii Mówionej", R. 3 (2013), s. 39-72.

Michalski B., Podstawowe problemy prawa prasowego, Warszawa 1998.

Nowicka A., Podmiot prawa autorskiego, [w:] Prawo autorskie, t. 13, red. J. Barta, Warszawa 2013, s. $85-93$.

Portelli A., What makes oral history different, [w:] The oral history reader, red. R. Perks, A. Thomson, b.m. 2003, s. 63-74.

Poźniak-Niedzielska M., Niewęgłowski A., Wprowadzenie. Pojęcie utworu, [w:] Prawo autorskie, t. 13, red. J. Barta, Warszawa 2013, s. 8-35. 
Ratkowska-Widlarz L., [rec.] Eksperyment(y) na oral history (J.P. Fereński, Kierunek eksperymentalny. Początki pierwszych w Polsce studiów kulturoznawczych, Wrocław 2012, ss. 191), „Wrocławski Rocznik Historii Mówionej”, R. 4 (2014), s. 276-282.

Sarabiński R.M., Utwór fotograficzny i jego twórca w polskim prawie, Kraków 2004.

Słownik jezzka polskiego, red. M. Szymczak, t. 1, Warszawa 1982.

Sobczak J., Ustawa prawo prasowe. Komentarz, Warszawa 1999.

Szaciński M., Reportaż w Prawie autorskim, „Palestra”, t. 41 (1997), nr 6-10.

Żeglińska A., Relacje oral history jako obiekty archiwalne, „Archiwa-Kancelarie-Zbiory”, nr 2(4) (2011), s. 145-154.

Wojciech Kucharski

Authorship and Copyright for Oral History Accounts in Poland
This article constitutes an attempt at creating a definition of copyright classification within the Polish legal system of oral history accounts. The author answers the questions of whether an oral history account is a scholarly work; who the author of such an account is; and what conditions need to be met in order for a person to be considered the author of the account in the context of copyright law. He discusses which copyright laws relate to such accounts, who holds the copyright to accounts, and what the scope of the copyright encompasses. The author also outlines the manner in which the issue of copyright law in practice affects the activities of institutions concerned with collecting and archiving oral history accounts.

Keywords: author of an oral history account, the oral history account as a scholarly work, co-creator, copyright 